\title{
Uptake and incorporation of inositol by preimplantation mouse embryos
}

\author{
M. T. Kane*, M. Norris and R. A. P. Harrison \\ Department of Molecular Embryology, AFRC Institute of Animal Physiology and \\ Genetics Research, Babraham, Cambridge, CB2 4AT, UK
}

\begin{abstract}
Summary. The uptake of myo-inositol by preimplantation mouse embryos was investigated using $\left[{ }^{3} \mathrm{H}\right]$ myo-inositol. Uptake increased about 12 -fold between one- and twocell stages and increased again at the blastocyst stage ( $>6$-fold compared with the two-cell stage). Uptake at the blastocyst stage was time and temperature dependent; it was stimulated by sodium, inhibited by glucose and appeared to take place mainly via a saturable mechanism. Uptake in the presence of $6.25 \mathrm{mmol}$ inositol $1^{-1}$ was $1424 \mathrm{fmol}$ inositol per blastocyst per h. About $10 \%$ of the $\left[{ }^{3} \mathrm{H}\right]$ inositol taken up by blastocysts during $8 \mathrm{~h}$ in culture was incorporated into lipid. Thin layer chromatography of the lipid showed that most of this inositol was incorporated into lipid material co-migrating with phosphatidylinositol with a small proportion co-migrating with phosphatidylinositol 4-phosphate.
\end{abstract}

Keywords: mouse; embryo; inositol; phosphoinositides

\section{Introduction}

There is much interest in the role of myo-inositol in cell regulation (Michell, 1989). First, inositol is an essential component of the phosphatidylinositol (PtdIns) cycle that appears to be a controlling system for cell proliferation in a wide range of normal and cancer cells (reviewed by Berridge, 1987). Inositol is incorporated into PtdIns which is converted successively to the polyphosphoinositides, PtdInsP and PtdIns(4,5) $\mathbf{P}_{2}$; stimulation of the cells by certain growth factors results in breakdown of PtdIns(4,5) $\mathrm{P}_{2}$ to produce two second messengers, diacylglycerol (DAG) and inositol 1,4,5-trisphosphate $\left(\operatorname{Ins}(1,4,5) \mathrm{P}_{3}\right)$, which act respectively to modulate specific protein phosphorylation processes and intracellular $\mathrm{Ca}^{2+}$ concentrations that, in turn, modulate a network of further cellular processes. Second, inositol is a precursor of the glycosylphosphoinositides (GPIs) that act as anchoring moieties for many membrane-bound proteins (reviewed by Low \& Saltiel, 1988); it has been postulated that the GPI anchor may confer special mobility on these proteins or that it may allow their ready release through cleavage of the anchor by specific phospholipases. Either situation might be expected to modulate cell - cell interactions. Third, it has recently been found that very many types of cell, both plant and animal, contain a complex system of inositol polyphosphates, some of which are present at remarkably high concentrations (reviewed by Downes \& Macphee, 1990). As yet, no clear physiological role has been demonstrated for these inositol polyphosphates (mostly InsP ${ }_{5}$ and $\operatorname{InsP}_{6}$ ), but their ubiquity is surely significant. Fourth, there is extensive evidence that inositol itself controls cell volume and cell osmolarity in certain types of cell (Kleinzeller \& Ziyadeh, 1990; McConnell \& Goldstein, 1990; Strange et al., 1991).

In nutritional studies with preimplantation embryos in culture, we have shown that inositol is essential for rabbit blastocyst growth and hatching of hamster blastocysts (Kane, 1988; Kane \&

*To whom correspondence should be addressed - present address: Department of Physiology, University College, Galway, Ireland. 
Bavister, 1988). We have also found that radiolabelled inositol is incorporated by rabbit blastocysts into the various phosphoinositides and inositol phosphates (M.M. Fahy \& M.T. Kane, unpublished data). Although it is clear that exogenous inositol is not essential for development of preimplantation mouse blastocysts, this does not show that inositol is not involved in mouse embryo development, since recycled endogenous inositol, already present in the oocyte, may be sufficient.

Here, we have investigated the uptake of inositol by the preimplantation mouse embryo and have examined briefly its possible incorporation into phosphoinositides. There appears to be no information available hitherto on the transport of inositol in the preimplantation embryo of any mammalian species.

\section{Materials and Methods}

\section{Collection and culture of embryos}

Fertilized embryos were recovered from immature $F_{1}(\mathrm{C} 57 \mathrm{BL} / 6 \mathrm{~J} \times \mathrm{CBA} / \mathrm{Ca})$ females; the females had been injected earlier with 7.5 iu pregnant mares' serum gonadotrophin (Intervet Ltd, Cambridge, UK) followed $48 \mathrm{~h}$ later by 7.5 iu human chorionic gonadotrophin (Intervet Ltd) to induce superovulation (Fowler \& Edwards, 1957) and paired with proven $F_{1}$ males. After detection of a vaginal plug on the morning after pairing (day 1 ), embryos were recovered in a phosphate-buffered saline medium (PBI/BSA; Whittingham \& Wales, 1969) containing $4 \mathrm{mg}$ bovine serum albumin $\mathrm{ml}^{-1}$ (BSA: Fraction V: Sigma Chemical Co. Ltd, Poole, Dorset, UK); one-cell embryos were collected on day I, two-cell embryos on day 2, eight-cell embryos on day 3 and blastocysts on day 4 . One-cell embryos were recovered in a cumulus clot by oviductal puncture, and the cumulus cells were then removed by incubation in 300 iu hyaluronidase $\mathrm{ml}^{-1}$ (Type V from ovine testis: Sigma Chemical Co. Ltd) in PBI/BSA for $3 \mathrm{~min}$. Oviducts were flushed with PBI/BSA to recover two-cell and eight-cell embryos, while blastocysts were flushed from the uterine horns. Embryos were collected between $11.00 \mathrm{~h}$ and $13.30 \mathrm{~h}$. All embryos were finally washed with modified T6 medium and, unless otherwise stated, they were cultured at $37^{\circ} \mathrm{C}$ in T6/BSA under paraffin oil at $5 \% \mathrm{CO}_{2}$ in air. The composition of T6 medium was as follows: $\mathrm{NaCl}\left(80.77 \mathrm{mmol} 1^{-1}\right), \mathrm{KCl}\left(1.48 \mathrm{mmol}^{-1}\right), \mathrm{NaHCO}_{3}\left(25 \mathrm{mmol}^{-1}\right)$, $\left.\mathrm{CaCl}_{2} \cdot 2 \mathrm{H}_{2} \mathrm{O}\left(\mathrm{I} \cdot 77 \mathrm{mmol}^{-1}\right), \mathrm{MgCl}_{2} \cdot 6 \mathrm{H}_{2} \mathrm{O}\right)\left(0.49 \mathrm{mmol} \mathrm{l}^{-1}\right), \mathrm{NaH}_{2} \mathrm{PO}_{4} \cdot 2 \mathrm{H}_{2} \mathrm{O}\left(0.39 \mathrm{mmol} \mathrm{l}^{-1}\right)$, glucose $(5.55 \mathrm{mmol}$ $\left.\mathrm{I}^{-1}\right)$, sodium pyruvate $\left(0.27 \mathrm{mmol}^{-1}\right)$, sodium lactate $\left(20.8 \mathrm{mmol}^{-1}\right)$, penicillin $\left(0.06 \mathrm{~g} \mathrm{l}^{-1}\right)$, streptomycin sulfate $\left(0.05 \mathrm{~g} \mathrm{l}^{-1}\right)$ and bovine serum albumin $\left(4 \mathrm{~g}^{-1}\right)$. This composition is modified from that in Howlett et al. (1987) by the use of the correct lactate concentration $20.8 \mathrm{mmol}^{-1}$ rather than the $0.45 \mathrm{mmol}^{-1}$ given in Howlett et al. (1987).

\section{Measurement of $\left.\left.\right|^{3} \mathrm{H}\right]$ inositol uptake by embryos}

The $\left[{ }^{3} \mathrm{H}\right]$ inositol used was myo-[2- $\left.{ }^{3} \mathrm{H}\right]$ inositol (TRK. 317: Amersham, Little Chalfont, Buckinghamshire, UK) with a specific activity of $18.9 \mathrm{Ci} \mathrm{mmol}^{-1}$. After culture, as described in the various experiments, the embryos were washed through three large drops (about $2 \mathrm{ml}$ ) of PB1/BSA. They were then placed in a scintillation vial in $0.5 \mathrm{ml}$ of $10 \%(\mathrm{w} / \mathrm{v})$ trichloroacetic acid, after which $10 \mathrm{ml}$ of scintillation cocktail (Packard Emulsifier Scintillator 299: Canberra Packard, Pangbourne, Reading, Berkshire, UK) was added; a small volume of the final wash medium was treated similarly, as a control. The samples were counted in a Packard Minaxi Tricarb 4000 scintillation counter.

The c.p.m. for the wash samples (usually <30 c.p.m.) were deducted from the c.p.m. for the embryo samples. The efficiency of counting for each embryo sample was calculated from its SIE (Spectral Index of External Standard) value and a plot of efficiency against SIE values that had been derived using a set of commercial quenched standards. Counting efficiencies were in the range $30-35 \%$. The efficiency values were used to convert c.p.m. to d.p.m. and, based on the specific activity of the $\left[{ }^{3} \mathrm{H}\right]$ inositol in the culture medium, inositol uptakes were expressed as femtomoles per embryo.

\section{Incorporation of $\left.\right|^{3} \mathrm{H} \mid$ inositol into phosphoinositides by blastocysts}

Blastocysts were cultured for $8 \mathrm{~h}$ in $1 \mathrm{mCi}\left[{ }^{3} \mathrm{H}\right]$ inositol ml ${ }^{-1}$, and were washed free of isotope. All blastocysts were added to $0.4 \mathrm{ml}$ of $\mathrm{PBI} / \mathrm{BSA}$ and the phospholipids extracted essentially as described by Roldan \& Harrison (1989) except that perchloric acid was substituted for trichloroacetic acid throughout. The lipid extract was taken up in chloroform: Folch standards were added to it; and the mixture was separated by thin layer chromatography (t.l.c.) on silica-gel $60 \mathbf{F}_{254}$-coated plates (E. Merck, Darmstadt, Germany) that had been activated by spraying with $1 \%(\mathrm{w} / \mathrm{v})$ potassium oxalate and heating in an oven for $1 \mathrm{~h}$ at $110^{\circ} \mathrm{C}$. The solvent was chloroform/methanol/water $/ \mathrm{conc}$. $\mathrm{NH}_{3}$ $(45: 35: 8: 2, \mathrm{v} / \mathrm{v})$. The spots corresponding to the phosphoinositide standards were located by spraying with iodine and scraped off, as were a series of strips in between the standard spots. Each scraping was transferred to a scintillation vial and counted after the addition of $1 \mathrm{ml}$ methanol and $10 \mathrm{ml}$ scintillation cocktail. 


\section{Statistical analysis}

The results of experiments were analysed by analysis of variance after first transforming the data by a logarithmic transformation (Steel \& Torrie, 1960). Data were further analysed as appropriate either by post hoc comparison of treatment means using Tukey's hsd test (Expt 1) or by orthogonal comparisons (Expts 2, 4 and 5) to test for linear and quadratic regression effects (Steel \& Torrie, 1960).

\section{Experiments and Results}

\section{Experiment 1: inositol uptake by embryos of different stages}

One-cell, two-cell and eight-cell embryos, as well as blastocysts, were cultured for $2 \mathrm{~h}$ in $25 \mu \mathrm{l}$ of T6/BSA medium containing $250 \mu \mathrm{Ci}\left[{ }^{3} \mathrm{H}\right]$ inositol $\mathrm{ml}^{-1}$ but no unlabelled inositol (the inositol concentration was therefore $\left.13 \cdot 2 \mu \mathrm{mol} \mathrm{I}^{-1}\right)$. The uptake of inositol varied greatly from one-cell embryo to blastocyst (Fig. 1). Mean uptake per embryo increased more than 12 -fold $(P<0 \cdot 01)$ from the one-cell $\left(0.23 \mathrm{fmol}\right.$ per embryo $\left.\mathrm{h}^{-1}\right)$ to the two-cell stage $(2.87 \mathrm{fmol}$ per embryo per $\mathrm{h})$. It then decreased slightly (not significantly different, $P>0.05)$ at the eight-cell stage $(2.04 \mathrm{fmol}$ per embryo $\left.\mathrm{h}^{-1}\right)$ but increased $(P<0.01)$ by about 9 -fold at the blastocyst stage ( $18.4 \mathrm{fmol}$ per embryo per h). It should be noted that the total increase from two-cell embryo to blastocyst was only 6.4-fold. Since the blastocysts incorporated inositol at the greatest rate and moreover represented the stage at which major changes of proliferation and differentiation begin, all further experiments were carried out only with blastocysts. It should be noted that the inositol uptake figures in these experiments represent net uptake, i.e. the total inositol taken up less any inositol or inositol product exported or diffusing back into the medium.

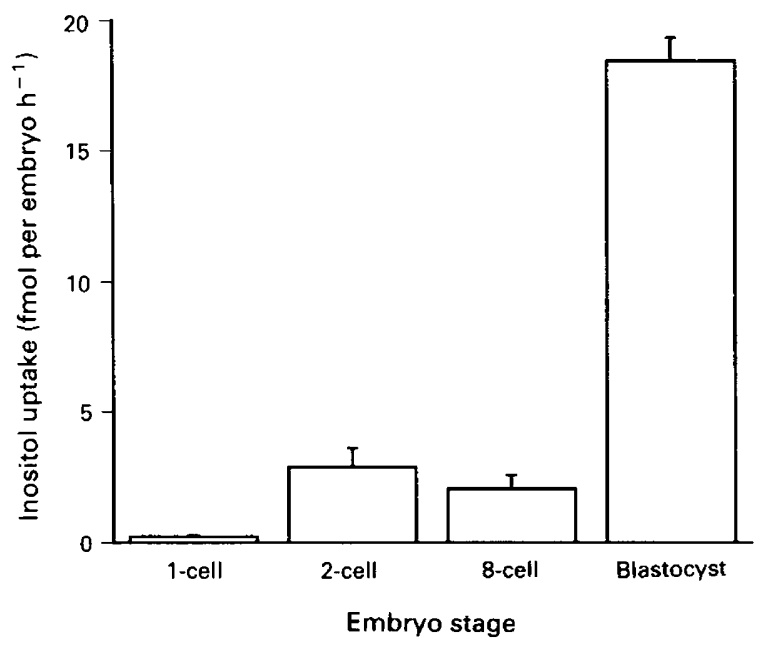

Fig. 1. Effect of developmental stage of mouse embryo on inositol uptake. Embryos were cultured at $37^{\circ} \mathrm{C}$ in the presence of $250 \mu \mathrm{Ci}\left[{ }^{3} \mathrm{H}\right]$ inositol ${ }^{-1}$ (equivalent to $13.2 \mu \mathrm{mol}$ inositol $\mathrm{l}^{-1}$ ) for $2 \mathrm{~h}$. Three replicates were performed, involving a total of 278 one-cell, 243 two-cell, 249 eight-cell and 210 blastocyst embryos. Plotted values are means \pm SEM.

\section{Experiment 2: effect of duration and temperature of culture on inositol uptake}

Blastocysts were cultured at either $23^{\circ} \mathrm{C}$ or $37^{\circ} \mathrm{C}$ in $12.5 \mu \mathrm{l}$ of T6/BSA medium containing $1 \mathrm{mCi}$ of $\left[{ }^{3} \mathrm{H}\right]$ inositol $\mathrm{ml}^{-1}$, and removed at 2, 4,6 and $8 \mathrm{~h}$ for determination of incorporation of labelled inositol. There was a clear-cut significant $(P<0.01)$ effect of culture temperature on inositol 
uptake (Fig. 2). After each of the periods of culture (2, 4, 6 and $8 \mathrm{~h}$ ), total inositol uptake was 3-5 times higher at $37^{\circ} \mathrm{C}$ than at $23^{\circ} \mathrm{C}$. At $37^{\circ} \mathrm{C}$, inositol uptake increased linearly from $2 \mathrm{~h}(145.6 \mathrm{fmol}$ per embryo $\left.\mathrm{h}^{-1}\right)$ to $6 \mathrm{~h}\left(371.8 \mathrm{fmol}\right.$ per embryo $\left.\mathrm{h}^{-1}\right)$ and then levelled off at $8 \mathrm{~h}(365.7 \mathrm{fmol}$ per embryo $\left.\mathrm{h}^{-1}\right)$. Statistical analysis indicated both a significant linear and quadratic effect of duration of culture on inositol uptake $(P<0.01)$. At $23^{\circ} \mathrm{C}$, uptake increased at all periods from $2 \mathrm{~h}$ (38.3 fmol per embryo $\left.\mathrm{h}^{-1}\right)$ to $8 \mathrm{~h}\left(81.8 \mathrm{fmol}\right.$ per embryo $\left.\mathrm{h}^{-1}\right)$ and the effect of duration of culture was linear throughout $(P<0.01)$. The greater uptake of inositol in this experiment, compared with that obtained in Expt $\mathrm{l}$, was due to the high level of $\left[{ }^{3} \mathrm{H}\right]$ inositol used $\left(1 \mathrm{mCi} \mathrm{ml}{ }^{-1}\right.$ as compared with $250 \mu \mathrm{Ci} \mathrm{ml}^{-1}$ in Expt 1), to determine whether mouse blastocysts would continue to incorporate $\left[{ }^{3} \mathrm{H}\right]$ inositol for up to $8 \mathrm{~h}$ under these conditions. This information was required for Expt 6 in which $\left[{ }^{3} \mathrm{H}\right]$ inositol at $1 \mathrm{mCi} \mathrm{ml^{-1 }}$ was used to label phosphoinositides sufficiently to allow their detection after t.l.c.

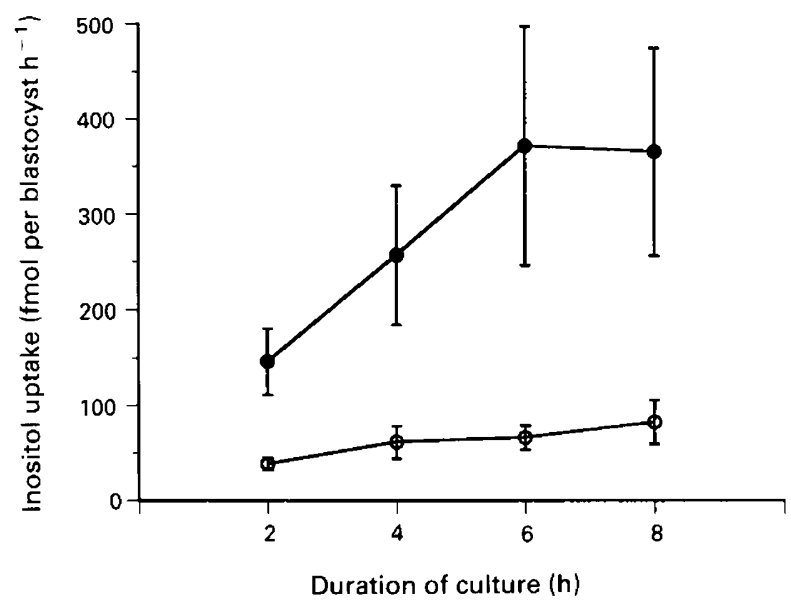

Fig. 2. Effect of duration of culture at two different temperatures $\left(23^{\circ} \mathrm{C}, O ; 37^{\circ} \mathrm{C}\right.$, $)$ on accumulation of inositol by mouse blastocysts. Embryos were cultured for $2 \mathrm{~h}$ in $1 \mathrm{mCi}$ $\left[{ }^{3} \mathrm{H}\right]$ inositol $\mathrm{ml}^{-1}$ (equivalent to $52.9 \mu \mathrm{mol}$ inositol $\mathrm{l}^{-1}$ ). Three replicates were performed. Plotted values are means \pm SEM based on 20-27 blastocysts per value.

\section{Experiment 3: effect of inositol concentration in the medium on inositol uptake}

Blastocysts were cultured for $2 \mathrm{~h}$ in $8 \mathrm{ml}$ of T6/BSA medium with $250 \mu \mathrm{Ci}\left[{ }^{3} \mathrm{H}\right]$ inositol ml ${ }^{-1}$ together with different concentrations of unlabelled inositol $\left(0,10,50,250,1250\right.$ and $\left.6250 \mu \mathrm{moll}^{-1}\right)$. Increasing the concentration of inositol in the medium dramatically increased inositol uptake (Fig. 3). Uptake in the presence of $6250 \mu \mathrm{mol}$ unlabelled inositol $\mathrm{l}^{-1}$ (total inositol concentration $6263 \mathrm{~mol}^{-1}$ ) was $1424 \mathrm{fmol}$ per embryo $\mathrm{h}^{-1}$ as compared with only $33 \mathrm{fmol}$ per embryo $\mathrm{h}^{-1}$ with $10 \mu \mathrm{mol}$ inositol $\mathrm{l}^{-1}$ (total inositol concentration $23 \mu \mathrm{mol} \mathrm{l}^{-1}$ ), nearly double that in Expt 1 . There were indications that the process was at least partly saturable, in that uptake was clearly levelling off above $1250 \mu \mathrm{mol}$ inositol $1^{-1}$.

\section{Experiment 4: effect of glucose concentration in the medium on inositol uptake}

Blastocysts were cultured for $2 \mathrm{~h}$ with $100 \mu \mathrm{Ci}\left[{ }^{3} \mathrm{H}\right]$ inositol $\mathrm{ml}^{-1}$ plus $10 \mu \mathrm{mol}$ unlabelled inositol $1^{-1}$ (total inositol concentration $15.3 \mu \mathrm{mol} 1^{-1}$ ), in $5 \mu$ l of T6/BSA medium in which the glucose content had been modified to yield final concentrations of $0,1,5$ and $25 \mathrm{mmol}^{-1}$. Inositol uptake was significantly inhibited $(P<0.01)$ by glucose in a log-linear fashion (Fig. 4). Even 


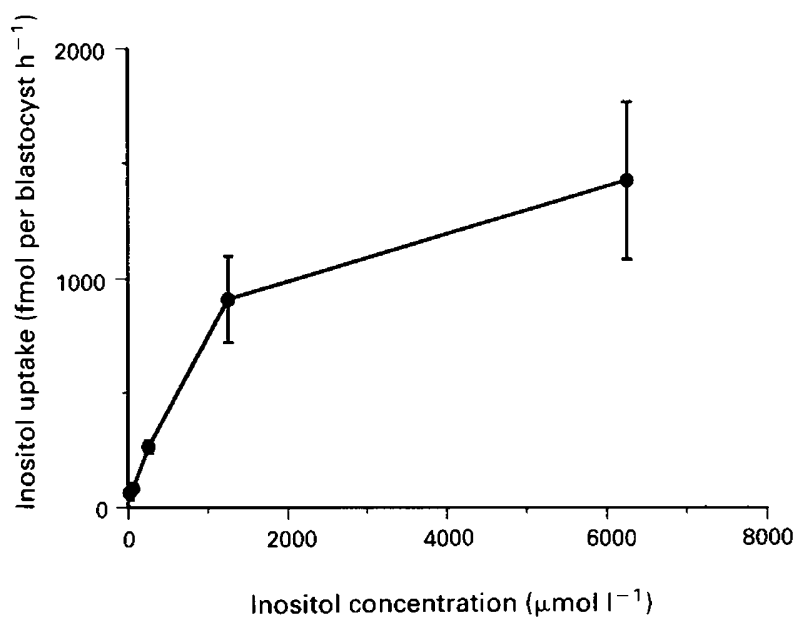

Fig. 3. Effect of inositol concentration on inositol uptake by mouse blastocysts. Embryos were cultured for $2 \mathrm{~h}$ in $250 \mu \mathrm{Ci}\left[{ }^{3} \mathrm{H}\right]$ inositol $\mathrm{ml}^{-1}$ and the indicated concentrations of total inositol. Four replicates were performed. Plotted values are means \pm SEM based on 16-20 blastocysts per value.

the lowest concentration of glucose tested $\left(1 \mathrm{mmol} \mathrm{l}^{-1}\right)$ decreased the uptake of inositol from 40.9 to $29.5 \mathrm{fmol}$ per embryo $\mathrm{h}^{-1}$. The concentration of glucose normally contained in $\mathrm{T} 6$ medium $\left(5.56 \mathrm{mmol} \mathrm{l}^{-1}\right)$ would therefore certainly account for the lower rates of incorporation by blastocysts seen in Expt 1.

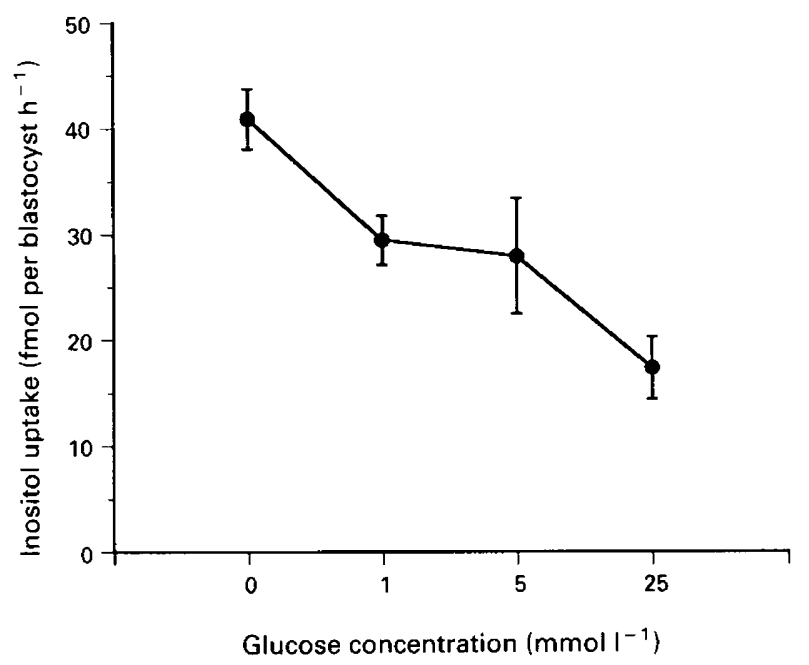

Fig. 4. Effect of glucose on inositol uptake by mouse blastocysts. Embryos were cultured for $2 \mathrm{~h}$ at $37^{\circ} \mathrm{C}$ with $100 \mu \mathrm{Ci}\left[{ }^{3} \mathrm{H}\right]$ inositol $\mathrm{ml}^{-1}$ plus $10 \mu \mathrm{mol}$ unlabelled inositol ml ${ }^{-1}(15 \cdot 3 \mu \mathrm{mol}$ total inositol $\mathrm{l}^{-1}$ ) together with the indicated concentration of glucose. Three replicates were performed. Plotted values are means \pm SEM based on $17-19$ blastocysts per value.

\section{Experiment 5: effect of sodium concentration in the medium on inositol uptake}

Blastocysts were cultured for $2 \mathrm{~h}$ with $100 \mu \mathrm{Ci}\left[{ }^{3} \mathrm{H}\right]$ inositol $\mathrm{ml}^{-1}$ plus $10 \mu \mathrm{mol}$ unlabelled inositol $\mathrm{I}^{-1}$ (total inositol concentration $15 \cdot 3 \mu \mathrm{mol} \mathrm{l}^{-1}$ ), in $5 \mu \mathrm{l}$ of $\mathrm{T} 6 / \mathrm{BSA}$ medium containing 
different concentrations of $\mathrm{Na}^{+}\left(21 \cdot 1,48 \cdot 2,75 \cdot 4,102 \cdot 5,129 \cdot 7 \mathrm{mmol}^{-1}\right)$. This was achieved by preparing a modified T6/BSA medium in which the $\mathrm{NaCl}$ and the $\mathrm{NaHCO}_{3}$ were replaced on an equimolar basis with choline chloride and choline bicarbonate, respectively (the sodium lactate and sodium pyruvate were not altered); the modified T6 medium was then mixed with unmodified T6 medium in the ratios 1:0, 3:1, 2:1, 1:1 and 0:1, respectively. Inositol uptake was clearly dependent on the concentration of $\mathrm{Na}^{+}$in the medium (Fig. 5). Decreasing the concentration of $\mathrm{Na}^{+}$significantly reduced inositol uptake in a linear manner $(P<0.01)$. The effect was reversible and not due to a toxic effect of the replacement of $\mathrm{Na}^{+}$by choline. This was shown by the fact that blastocysts cultured in low $\mathrm{Na}^{+}$medium $\left(21.1 \mathrm{mmol} \mathrm{l}^{-1}\right)$ for $2 \mathrm{~h}$ greatly increased their hourly uptake of

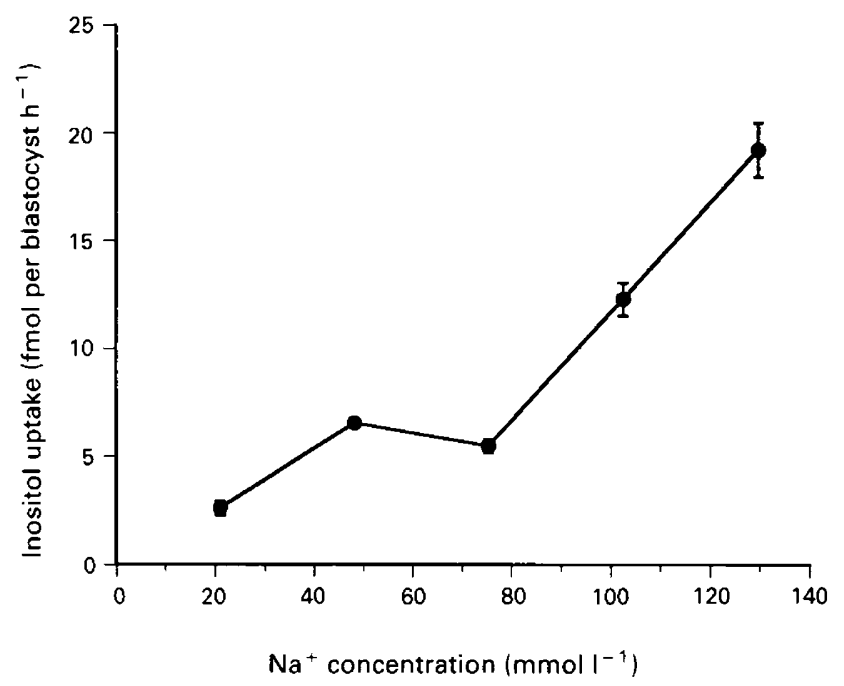

Fig. 5. Effect of $\mathrm{Na}^{+}$concentration on inositol uptake by mouse blastocysts. Embryos were cultured for $2 \mathrm{~h}$ at $37^{\circ} \mathrm{C}$ with $100 \mu \mathrm{Ci}\left[{ }^{3} \mathrm{H}\right]$ inositol ml ${ }^{-1}$ plus $10 \mu \mathrm{mol}$ unlabelled inositol $1^{-1}$ $\left(15.3 \mu \mathrm{mol}\right.$ total inositol $\left.1^{-1}\right)$ in culture media whose $\mathrm{Na}^{+}$content had been modified to yield the final concentrations indicated. Plotted values are means \pm SEM based on 30-33 blastocysts per value in three replicates (except for the $75 \cdot 4 \mathrm{mmol} \mathrm{Na}^{+} 1^{-1}$ concentration which is based on two replicates and 20 blastocysts).

Table 1. Effect of culture in low $\mathrm{Na}^{+}$medium followed by culture in normal $\mathrm{Na}^{+}$medium on inositol uptake by mouse blastocysts

\begin{tabular}{|c|c|c|c|}
\hline \multirow[b]{2}{*}{ Culture conditions } & \multirow{2}{*}{$\begin{array}{l}\text { Number of } \\
\text { blastocysts }\end{array}$} & \multicolumn{2}{|c|}{$\begin{array}{c}\text { Inositol uptake } \\
\text { (fmol per blastocyst) }\end{array}$} \\
\hline & & Per h & Total \\
\hline $4 \mathrm{~h}$ in $21 \cdot 1 \mathrm{mmol} \mathrm{Na}{ }^{+} 1^{-1}$ & 12 & $4 \cdot 45$ & $17 \cdot 8$ \\
\hline $2 \mathrm{~h}$ in $129.7 \mathrm{mmol} \mathrm{Na}^{+} 1^{-1}$ & 13 & $21 \cdot 8$ & $43 \cdot 5$ \\
\hline $\begin{array}{l}2 \mathrm{~h} \text { in } 21.1 \mathrm{mmol} \mathrm{Na}{ }^{+} 1^{-1} \text { plus } \\
2 \mathrm{~h} \text { in } 129.7 \mathrm{mmol} \mathrm{Na}^{+} 1^{-1}\end{array}$ & 12 & $16 \cdot 4$ & $65 \cdot 8$ \\
\hline
\end{tabular}


inositol when transferred to normal $\mathrm{Na}^{+}$-containing T6/BSA medium for a further 2-h culture period (Table 1).

\section{Experiment 6: incorporation of inositol into phosphoinositides}

One hundred and thirty eight blastocysts were cultured for $8 \mathrm{~h}$ in the presence of $1 \mathrm{mCi}$ $\left[{ }^{3} \mathrm{H}\right]$ inositol $\mathrm{ml}^{-1}$ in $12.5 \mu \mathrm{l}$ of T6/BSA medium without glucose. At the end of this period, the uptake of inositol into phosphatidylinositol (PtdIns) and the polyphosphoinositides (PtdIns4P and PtdIns $\left.(4,5) \mathrm{P}_{2}\right)$ was assessed. Inositol uptake per blastocyst was $571 \mathrm{fmol}$, of which $60.7 \mathrm{fmol}$ $(10 \cdot 6 \%)$ had been incorporated into extractable lipids. After subjecting the lipid extract to t.l.c., the equivalent of $42.0 \mathrm{fmol}$ per blastocyst $(69.2 \%$ of that applied to the plate) was recovered. Of this, $79.8 \%$ (33.5 fmol per blastocyst) co-migrated with the PtdIns standard, and $1.1 \%(0.47 \mathrm{fmol})$ co-migrated with the PtdInsP standard; no detectable label was co-migrated with PtdInsP $\mathbf{P}_{2}$. However, $7 \cdot 3 \%(3.06 \mathrm{fmol})$ co-migrated with unidentifiable material running faster than PtdIns, close to phosphatidylserine.

\section{Discussion}

A number of conclusions concerning the uptake of inositol by preimplantation mouse embryos emerge clearly from the present experiments. First, the uptake process is stage dependent, increasing by about an order of magnitude at the two-cell and blastocyst stages. Second, uptake at the blastocyst stage is both time and temperature dependent; the transport process is stimulated by $\mathrm{Na}^{+}$and inhibited by glucose, and there is also evidence that it is saturable by higher concentrations of inositol in the culture medium. Third, a considerable proportion (some $8 \%$ ) of the transported inositol appears to be incorporated into PtdIns with a very small amount into PtdIns4P. The stage dependence of the uptake process is particularly interesting. Proportionately the increase was greatest (12-fold) at the two-cell stage. This is not due to an increase in protein concentration, since the protein content of the mouse embryo remains relatively unchanged at $20 \mathrm{ng}$ from two-cell to early blastocyst (Brinster, 1967); it cannot be accounted for by an increase in surface area of the cell, since this would be at most about $26 \%$ between the one- and two-cell stage (assuming equal volumes of one-cell and two-cell contents). The increase must therefore be due either to increased membrane permeability to inositol or to synthesis (or activation) of inositol carrier proteins. Gardner \& Leese (1988) have shown a similar increase in glucose uptake in mouse embryos between the one- and two-cell stages. On the other hand, the increase in uptake at the blastocyst stage ( 6.4 fold compared with the value obtained at the two-cell stage) may indeed be partly due to an increase in the embryonic surface area exposed to the culture medium as the blastocyst starts to expand. Again, there is a similar increase in glucose uptake at the blastocyst stage (Gardner \& Leese, 1988).

There do not appear to have been any previous studies investigating the uptake of inositol by preimplantation mammalian embryos. There are, however, a number of studies investigating the uptake of inositol by various types of tissues and cells, e.g. Caspary \& Crane (1970), hamster small intestine; Haneda et al. (1990), rat glomerular cells; Simmons et al. (1990), human leucocytes, and Weigensberg et al. (1990), postimplantation rat embryos. The general picture to emerge from these studies is that a major part of inositol transport into cells, at least at physiological concentrations of inositol, is mediated by a specific inositol carrier or transporter that is temperature-dependent, energy-dependent, $\mathrm{Na}^{+}$-dependent and saturable. Although this carrier is distinct from the normal glucose transporter in cells, transport by the inositol carrier is competitively inhibited by glucose. Our data provide clear evidence that a similar type of carrier is present in mouse blastocysts. The inositol carrier demonstrated in our studies is not the glucose carrier, because the latter is not physiologically $\mathrm{Na}^{+}$-dependent in preimplantation mouse embryos (Gardner \& Leese, 1988). 
Although we have not carried out any specific studies relating to the energy dependence of the carrier, we found that, in the presence of dinitrophenol $\left(0.5 \mathrm{mmol}^{-1}\right)$, five blastocysts incorporated inositol during $2 \mathrm{~h}$ at a rate only $44 \%$ (on a per embryo basis) of that shown by eight untreated blastocysts.

Studies in other tissues have revealed the presence of a non-saturable, $\mathrm{Na}^{+}$-independent, non-competitive mechanism of transport which may be more important at supraphysiological concentrations of inositol (Khatami, 1988; Isaacks et al., 1989; Simmons et al., 1990). Our data do not allow us to determine whether such a mechanism exists in mouse blastocysts. The question could be answered by culturing blastocysts in differing concentrations of inositol in media with and without $\mathrm{Na}^{+}$(Haneda et al., 1990), and accurate estimates of the $K_{\mathrm{m}}$ and the $V_{\max }$ of the saturable inositol carrier in mouse blastocysts must await such an approach.

The available information on concentrations of inositol in the female reproductive tract is extremely limited. Gregoire et al. (1962) reported concentrations of free inositol of $2.6 \mathrm{mg}$ in $100 \mathrm{ml}$ ( $\left.144 \mu \mathrm{mol} \mathrm{l}^{-1}\right)$ and $7.4 \mathrm{mg}$ in $100 \mathrm{ml}\left(411 \mu \mathrm{mol}^{-1}\right)$ in the oviductal and uterine fluid of the rabbit.

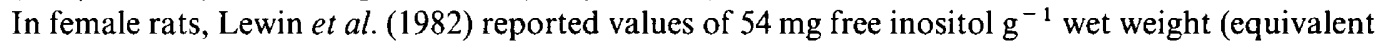
to $300 \mathrm{~mol}^{-1}$ ) in proestrous uterine fluid with about 10 -fold and 3-5-fold higher amounts in the oviductal and uterine tissues, respectively. In contrast, Lutwak-Mann (1959) was unable to detect free inositol in the rabbit blastocyst. The optimal concentration for growth of rabbit blastocysts lies in the range $15-375 \mu \mathrm{mol}^{-1}$ (Kane, 1989).

Our data on the incorporation of inositol into phosphoinositides by mouse blastocysts are essentially preliminary and do not provide definitive proof of the identity of the phosphoinositides. However, they seem to show that a relatively high proportion of the transported inositol is used to form PdtIns with a much smaller proportion going to form PtdIns4P. Our failure to detect any incorporation into PtdIns $(4,5) \mathrm{P}_{2}$, the immediate precursor of the second messengers diacylglycerol and $\operatorname{Ins}(1,4,5) \mathrm{P}_{3}$, might suggest that the PtdIns cycle is not fully active at this embryonic stage. However, a number of other explanations might be proposed, including the fact that the metabolically active polyphosphoinositide pools are only a fraction of their total mass (e.g. King et al., 1987); whereas internalized inositol is usually readily incorporated into PtdIns (by direct combination with CDP-diglyceride), incorporation into PtdIns4P and PtdIns(4,5) $\mathrm{P}_{2}$ is always limited. The appearance of significant label (presumed to be inositol) in material clearly neither PtdIns nor its phosphorylated derivatives was intriguing; it is possible that this was a glycosylated phosphatidylinositol similar to that demonstrated by Saltiel et al. (1987) and possibly a precursor of membrane-protein anchoring moieties (Low \& Saltiel, 1988). In work with rabbit blastocysts, we have shown that $\left[{ }^{3} \mathrm{H}\right]$ inositol is incorporated into PtdIns $(4,5) \mathrm{P}_{2}$ as well as PtdIns and PtdIns4P (M.M. Fahy \& M.T. Kane, unpublished data).

Available information on the role of inositol and the PtdIns cycle in the molecular physiology of development has been reviewed by Busa (1988). For example, injection of $\mathrm{Li}^{+}$into blastomeres of the 32-cell Xenopus embryo disrupts normal development and this effect is prevented by coinjection of $m y o$-inositol; it is postulated that $\mathrm{Li}^{+}$interferes with normal operation of the PtdIns cycle by inhibiting the enzyme that breaks down inositol monophosphate, thus preventing normal intracellular recycling of inositol for phosphoinositide synthesis. Izquierdo \& Becker (1982) have shown that culture of mouse embryos in the presence of $\mathrm{Li}^{+}$salts inhibits formation of the inner cell mass but not the trophectoderm. There is also evidence that phorbol esters, one of the actions of which is to activate protein kinase $\mathrm{C}$ in a similar way to DAG, stimulate premature blastocyst development in the mouse (Sawicki \& Mystowska, 1981). We believe that the present work opens up the possibility of investigating the role of inositol in preimplantation mouse embryos at a molecular level, which may allow elucidation of these tantalizing observations.

We thank the British Council for travel funding and EMBO for provision of a short-term fellowship to M. T. Kane to carry out this work. We thank D. J. Lander for carrying out the t.l.c. separation of phosphoinositides. 


\section{References}

Berridge, M.J. (1987) Inositol lipids and cell proliferation. Biochimica et Biophysica Acta 907, 33-45.

Brinster, R.L. (1967) Protein content of the mouse embryo during the first five days of development. Journal of Reproduction and Fertility 13, 413-420.

Busa, W.B. (1988) Roles for the phosphatidylinositol cycle in early development. Philosophical Transactions of the Royal Society London. Series B 320, 415-426.

Caspary, W.F. \& Crane, R.K. (1970) Active transport of myo-inositol and its relation to the sugar transport system in hamster small intestine. Biochimica et Biophysica Acta 203, 308-316.

Downes, C.P. \& MacPhee, C.H. (1990) Myo-inositol metabolites as cellular signals. European Journal of Biochemistry 193, 1-18.

Fowler, R.E. \& Edwards, R.G. (1957) Induction of superovulation and pregnancy in mature mice by gonadotrophins. Journal of Endocrinology 15, 374-384.

Gardner, D.K. \& Leese, H.J. (1988) The role of glucose and pyruvate transport in regulating nutrient utilization by preimplantation mouse embryos. Development 104, $423-429$.

Gregoire, A.T., Gongsakdi, D. \& Rakofi, A.E. (1962) The presence of inositol in genital tract secretions of the female rabbit. Fertility and Sterility 13, 432-435.

Haneda, M., Kikkawa, R., Arimura, T., Ebata, K., Togawa, M., Maeda, S., Sawada, T., Horide, N. \& Shigeta, Y. (1990) Glucose inhibits myo-inositol uptake and reduces myo-inositol content in cultured rat glomerular mesangial cells. Metabolism 39, 40-45.

Howlett, S.K., Barton, S.C. \& Surani, M.A. (1987) Nuclear cytoplasmic interactions following nuclear transplantation in mouse embryos. Development 101, 915-923.

Isaacks, R.E., Lai, L.L., Kim, C.Y., Goldman, P.H. \& Kim, H.D. (1989) Studies on avian erythrocyte metabolism. XVII. Kinetics and transport properties of myo-inositol in chicken reticulocytes. Archives of Biochemistry and Biophysics 274, 564-573.

Izquierdo, L. \& Becker, M.I. (1982) Effect of $\mathrm{Li}^{+}$ on preimplantation mouse embryos. Journal of Embryology and Experimental Morphology 67, 51-58.

Kane, M.T. (1988) The effects of water soluble vitamins on the expansion of rabbit blastocysts. Journal of Experimental Zoology 245, 220-223.

Kane, M.T. (1989) Effects of the putative phospholipid precursors, inositol, choline, serine and ethanolamine, on formation and expansion of rabbit blastocysts in vitro. Journal of Reproduction and Fertility 87, 275-279.

Kane, M.T. \& Bavister, B.D. (1988) Vitamin requirements for development of eight-cell hamster embryos to hatching blastocysts in vitro. Biology of Reproduction 39, $1137-1143$.

Khatami, M. (1988) Carrier-dependent and carrierindependent uptake of myo-inositol in cultured retinal pigment epithelial cells: activation by heat and concentration. Biochemistry and Cell Biology 66, 942-950.

King, C.E., Stephens, L.R., Hawkins, P.T., Guy, G.R. \& Michell, R.H. (1987) Multiple metabolic pools of phosphoinositides and phosphatidate in human erythrocytes incubated in a medium that permits rapid transmembrane exchange of phosphate. Biochemical Journal 244, 209-217.

Kleinzeller, A. \& Ziyadeh, F.N. (1990) Cell volume regulation in epithelia - with emphasis on the role of osmolytes and the cytoskeleton. In Cell Volume Regulation, pp. 59-86. Ed. K. W. Beyenbach. Karger, Basel.

Lewin, L.M., Yannai, Y., Melmed, S. \& Weiss, M. (1982) myo-Inositol in the reproductive tract of the female rat. International Journal of Biochemistry 14, 147-150.

Low, M.G. \& Saltiel, A.R. (1988) Structural and functional roles of glycosylphosphatidylinositol in membranes. Science 239, 268-275.

Lutwak-Mann, C. (1959) Biochemical approach to the study of ovum implantation in the rabbit. In Implantation of Ova, Memoirs of the Society for Endocrinology, No.6, pp. 35-46. Ed. P. Eckstein. Cambridge University Press, Cambridge.

McConnell, F. \& Goldstein, L. (1990) Volume regulation in elasmobranch red blood cells. In Cell Volume Regulation, pp. 114-131. Ed. K. W. Beyenbach. Karger, Basel.

Michell, R.H. (1989) Inositol lipids and phosphates in growing, stimulated and differentiating cells. Biochemical Society Transactions 17, 1-3.

Roldan, E.R.S. \& Harrison, R.A.P. (1989) Polyphosphoinositide breakdown and subsequent exocytosis in the $\mathrm{Ca}$ /ionophore-induced acrosome reaction of mammalian spermatozoa. Biochemical Journal 259, 397-406.

Saltiel, A.R., Sherline, P. \& Fox, J.A. (1987) Insulinstimulated diacylglycerol production results from the hydrolysis of a novel phosphatidylinositol glycan. Journal of Biological Chemistry 262, 1116-1121.

Sawicki, W. \& Mystowska, E.T. (1981) Phorbol ester-mediated modulation of cell proliferation and primary differentiation of mouse preimplantation embryos. Experimental Cell Research 136, 455-458.

Simmons, D., Bomford, J. \& Ng, L.L. (1990) myoInositol influx into human leucocytes: methods of measurement and the effect of glucose. Clinical Sciences 78, 335-341.

Steel, R.G.D. \& Torie, J.H. (1960) Principles and Procedures of Statistics. McGraw-Hill Book Company, Inc., New York.

Strange, K., Morrison, R., Heilig, C.W., DiPietro, S. \& Gullans, S.R. (1991) Upregulation of inositol transport mediates inositol accumulation in hyperosmolar brain cells. American Journal of Physiology 260, C784-C790.

Weigensberg, M.J., Garcia-Palmer, F-J. \& Freinkel, N. (1990) Uptake of myo-inositol by early-somite rat conceptus. Transport kinetics and effects of hyperglycemia. Diabetes 39, 575-582.

Whittingham, D.G. \& Wales, R.G. (1969) Storage of twocell mouse embryos in vitro. Australian Journal of Biological Sciences 22, 1065-1068.

Received 7 October 1991 